\title{
Sport og doping \\ - analyse af en aktuel hysteri
}

\section{Af Verner Mфller}

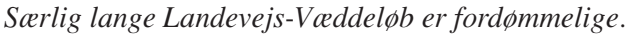
Rytterne ase sig afsted ved Dag og ved Nat, $i$ hede og kulde, tit i radsomt Fore, uden at vare sig for Forhindringer, $i$ den velbekendte usunde Krebsestilling, og nasten uden Tфj paa.

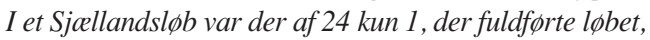
og for adskilliges Vedkommende var Folgen Hjarnesvakkelse, Lemlastelser og anden Sygelighed. ${ }^{1}$

\section{Indledning}

Da cykelrytteren Bjarne Riis, hin mindeværdige dag i 1996, faldt tilbage gennem favoritfeltet for sekunder senere at sætte i et uimodståeligt kraftfuldt ryk væk fra gruppen og fighte sig op ad bjerget Hautacam for at konsolidere sin gule førertrøje, begejstrede han alverdens cykelentusiaster. Herhjemme hensatte præstationen publikum i en tilstand af eufori. Det han gjorde var så koldt, så overlegent og så stor en iscenesættelse af sejren, at også et mere cykelfremmed sportspublikum måtte overgive sig.

Tour de France 1998 blev et antiklimaks. Forventningen om atter at se et storslået cykeldrama forblev uindfriet. Dramatikken blev flyttet uden for cykelsporten, og helterollen overtaget af toldere og kommissærer. Efter toldernes ikke ubetydelige fund af dopingmidlet erythropoetin (EPO) $i$ en Festina-bil rettede pressen opmærksomheden mod dopingsagen. Sportsbegivenheden blev i forhold hertil sekundær.
Mediedækningen blev over en bred front en uskøn blanding af kriminal- og sportsreportage. Grænsen mellem sportens univers og hverdagsvirkeligheden var med ét blevet brudt.

For (cykel)sporten og i særdeleshed for Tour de France udviklede sagen sig nærmest katastrofalt. Efter nogen tids overvejelser valgte løbsleder Jean Marie Leblanc at smide Festina-holdet på porten. Man forstår han gjorde det nødtvungent, eftersom det ikke alene betød farvel til Frankrigs store håb og kæledægge Richard Virenque, men også til et af feltets stærkeste og mest spektakulære hold med navne som den tidligere Once-kaptajn, vinder af Spanien rundt 1997 Alex Zülle, verdensmester Laurent Brochard og den uhyre stærke hjælperytter Laurent Dufaux. Med Festina ude så det umiddelbart ud til, at alle trusler mod det kun lidt stærkere Telekom-hold, med bl.a. de to sidste års vindere Jan Ullrich og Bjarne Riis, var væk.

Ganske vist viste Casino-mandskabet sig i nogen grad i stand til at angribe. Tidligt i løbet med Bo Hamburger og Jacky Durand som de ivrigste, senere i bjergene ved især Rodolfo Massi der erobrede bjergtrøjen og beholdt den, indtil han måtte forlade løbet efter at være blevet taget til afhøring af politiet. Rygter ville vide, at det var for mistanke om videresalg af dopingmidler.

Herefter var der kun Marco Pantani til at 
holde dette års udgave i live med sin storslåede kørsel på den hårde bjergetape fra Grenoble til Les-deux-Alpes, hvor han med sit angreb på Col de Galibier i realiteten knuste Ullrich og dermed Telekoms mulighed for at vinde Tour'en for tredje år i træk. Pantani, der havde sat næsten et minut til på den diminutive prolog, var som forvandlet. Enten er han forbløffende cool og eminent til at bluffe, eller også har han en overmenneskelig evne til at køre sig i form. Sådan lød den sportsjournalistiske forklaring på Pantanis spektakulære massakre uden mindste antydning af muligheden for, at hans forvandling kunne have noget at gøre med det nye hyperfarlige, men højpotente dopingmiddel PFC, der giver en markant forbedret iltoptagelse.

Midt i alle afsløringer blev Pantani tilsyneladende gjort til genstand for drømmen om renhed og uskyld: den fair sejr i den rette sportsånd.

Af hensyn til samme drøm blev Riis afkrævet svar på spørgsmålet, om han nogensinde havde brugt doping. »Jeg er aldrig blevet testet positiv, og jeg går ind for en ren sport«, svarede han ærligt. Men det var ikke nok. Stik os hellere en løgn og lad os drømme videre om dit livs form i 1996udgaven, hvor du ikke bare vandt, men sønderknuste et felt med folk som nu har indrømmet systematisk brug af EPO gennem flere år. Det var underteksten på det senere: 'Ja eller nej, Bjarne?', hvortil han svarede: »Nej selvfølgelig har jeg ikke det! Ligner jeg måske en junkie? « Dette svar virkede befriende. Underligt nok for $\varnothing v$ rigt for så vidt Zülle, Dufaux og de andre bekendende dopingbrugere bestemt også ser sunde og raske ud.

Men det afgørende var åbenbart, at Riis nu i utvetydige vendinger havde erklæret sig 'ren'. Dermed var det på ny muligt at mobilisere naiviteten. 'Problemet' var ikke omfattende og strukturelt, men begrænset til enkelte brodne kar, som skulle bekæmpes. Retableringen af illusionen om den rene dopingfri (cykel)sport kunne så småt påbegyndes.

Artiklen her udspringer af en undren over denne illusions åbenbare vigtighed. Den er fremdeles et bidrag til forståelse af, hvorfor doping opfattes som et særligt problem?

\section{Argumenter mod doping}

I de stormfulde dage under og umiddelbart efter Tour'en vrimlede medierne med kommentarer, der markerede en afstandtagen fra brug af doping. Og den massive fordømmelse kom ikke overvejende fra sportens traditionelle kritikere, men derimod fra idrætsledere og andre, der ellers erklærede sig sporten positivt stemt, men som følte sig bedraget.

Argumenterne, der blev fremført i debatten, var dels de klassiske, at doping er unfair snyd, der nedbryder forestillingen om konkurrence på lige vilkår; det er usundt; det er unaturligt. Dels nogle nyere argumenter som at det $\varnothing$ delægger sporten som identifikatorisk mulighed, hvorfor den i sidste ende bliver uinteressant; doping medfører, at det gode eksempel for børn og unge fortabes. Disse argumenter er fælles om at udtrykke bekymring for, at doping strider mod sportens ånd, der på den ene side er forbundet med dyder som sportsmanship og fairness, og på den anden side forestillinger om sundhed, naturlighed og renhed.

Når idrætsledere og folk uden for sportens verden bekymrer sig om brugen af doping, er det ikke mindst, fordi de værdsætter sporten som en karakterdannende eller opdragende faktor. Dopingbrugen synes netop at underminere den som sådan. Det er sportens moralske værdi eller rettere: 
Det er sportens værdi, som i væsentlig grad forbindes med det moralske, der er på spil. Og derfor omtales brugen da også konsekvent som misbrug, skønt misbrug almindeligvis opfattes som svækkende, ikke styrkende. Hvis ikke det kan lade sig gøre at bevare (forestillingen om) sportens renhed, hvilke konnotationer vil der så for fremtiden knytte sig til standardvendinger som »en rigtig sportsmand « og »sportslig optræden «? Med erosionen af de moralske, pædagogiske og sundhedsmæssige begrundelser, hvordan skal man da fremover kunne argumentere for tilskud til sporten?

\section{Professionalisme og doping}

Den aktuelle fordømmelse af doping ligner det sene 1800-tals fordømmelse af professionalisme, hvoraf Dansk Idræts-Forbund udsprang. Hvor man tidligere uden kvababbelser dystede om pengepræmier, blev amatørbegrebet fremelsket som et ideologisk bolværk mod arbejderklassen fra borgerskabets side. ${ }^{2}$ Forherligelsen af amatøren holdt sig langt op i dette århundrede. Så sent som i 1960'erne var professionelle fodboldspillere i den hellige amatørismes navn endnu udelukket fra at spille på landsholdet. Forskellen er imidlertid, at der med dopingproblemet står mere på spil for idrætten selv.

I professionalismen så amatøridrættens fortalere en trussel mod idrættens dyder, men det var samtidig i kraft af disse, at professionaliseringen af sporten, som vi kender den i dag, var mulig. Sportens positive omdømme var afgørende for, at sponsorer fandt den værd at investere i. Professionaliseringen har da heller ikke i sig selv haft negative konsekvenser for sportens omdømme, om end der har været en tendens til at koble sponsorkrav, pengepræmier og dopingfristelsen sammen.
Professionalisme i sport er blevet bredt accepteret, og denne forandring er sket uden, at sportsånden har taget ubodelig skade. Fairness og sportsmanship trives trods al snak om dopingsnyd stadig. I forhold til professionalisme er der de seneste tredive år generelt sket et holdningsskift, hvilket man også bemærker i sproget, hvor man nu til dags næppe smigres ved at blive kaldt »en ren amatør«. At karakteriseres som amatør synes i dag på linje med det antikke Grækenlands betegnelse for datidens amatører, privat- og lægmænd: idiotes. $^{3}$

Når dopingbrugen, der på sin vis indtages til fremme af eliteidrætten(s præstationer), ikke bare kan knæsættes af idrætsorganisationerne, som professionalismen er blevet, skyldes det, at den på anden vis er en direkte trussel mod eliteidrættens - og især dens institutioners - $\emptyset$ konomi. Man forstår derfor udmærket, at eksempelvis Team Danmark (institutionen til fremme af dansk eliteidræt) markerer en uforsonlig holdning, også efter at IOCs præsident Juan Antonio Samaranch har udtalt sig til fordel for en lempelse af dopingreglerne. I Politiken kunne man således læse, at »Lederen af Team Danmarks kontroludvalg, Finn Mikkelsen, mener, at legaliseringstankerne er 'helt hen i vejret'. « ${ }^{4}$ Ser man nøjere til, er de klassiske argumenter til støtte for denne uforsonlige holdning imidlertid ikke aldeles solide.

\section{Sportsånden i og uden for sporten}

Svagheden er, at argumenterne er funderet sportseksternt, hvad enten de fremføres i sportskritisk ærinde eller til forsvar for sportens opdragende og karakterdannende værdi. Skønt der til forskellige tider har 
været forskel på idealerne og på, hvad man har tilstræbt at opdrage til, har fællesnævnerne været mådehold og besindighed. Disse dyder er ideologisk blevet gjort til indbegrebet af sportens ånd. Dermed er sportsånden og sportens vasen paradoksalt blevet til dels modstridende begreber.

Sportsånden knytter sig til det holdningsmæssige. Hyldet i fraser som: »Tab og vind med samme sind «, og »Det vigtigste er ikke at vinde, men at være med «, dyrkes den på bekostning af sportens væsen, der viser sig i »viljen til sejr« og udtrykkes i mottoet: »Hurtigere, højere, stærkere«.

Sportens væsen er grundlæggende en stræben mod det ypperste. Den, der ikke påskønner sportens væsen, vil ikke interessere sig for sport. Hermed ikke sagt at den, der påskønner, også forstår. Devalueres sejrens betydning (i virkeligheden er den ingenting) er man på vej ud af sportens tryllekreds. Man opdager, at ærgrelsen ved nederlag bliver mindre, men det samme gør glæden ved sejr. Eliteidrætsudøvere kender denne devaluering som et varsel om, at karrieren går på hæld. Træningsintensiteten går ned, og i konkurrence bliver den nødvendige kraftanstrengelse for at sejre stadig vanskeligere at mobilisere. Vinderen er som regel - især selvfølgelig i udholdenhedsidrætter - den blandt ligemænd, der er i stand til at presse sig længst ud mod sit eget sammenbrud. Succes i eliteidræt stiller voldsomme fordringer. Det er i denne verden en afgørende kvalitet, at man kan 'æde' sig selv.

Naturligvis kan sport dyrkes, uden den fuldstændige fiksering på resultater og fremgang, der findes i forbindelse med eliteidræt og som kan have karakter af besættelse. Kendetegnende for sporten er imidlertid, at den, også når den dyrkes på lavt niveau, kan gribe udøvere, så sejren, i det mindste momentant, bliver af en sådan vigtighed, at man anstrenger sig i usædvanlig grad. Et vaesentligt træk ved sporten er, at den animerer til overdrivelse.

Øjensynligt er det kun sportens udøvere, der endnu er i stand til at forlige disse umiddelbart uforligelige begreber: væsen og ånd. Forudsætningen for forligelsen er nemlig, at man forstår sportsånden som hjemmehørende i sportens verden, som er anderledes end den almindelige verden, den eksisterer i og beriger. Sportsånden kan ikke beherskes eller regelbindes. Når der i en anden og måske større sags tjeneste tales om sportsånd uden for sportens gebet, visner begrebet. Det kan ikke fungere som forkromet. Kun i sporten hersker sportsånden (om end den muligvis kan sætte sit præg på udøverens holdning i øvrigt), og det uden negative følger for sportens væsen.

Netop i cykelsporten har man aktuelt kunnet se dette manifesteret. Ingen angiver, anklager eller fordømmer hinanden i dopingsager, hvilket undrer udenforstående, der nægter at indse, at rytterne ikke identificerer noget dopingproblem og ikke opfatter doping som moralsk forkasteligt snyd, før de som nu tvinges til det. ${ }^{5}$

Årsagen til dette er ikke, at der mangler moral blandt rytterne, blot hersker der en anden orden. Sportsånden viser sig i overholdelsen af en anden kodeks. Man går f.eks. ikke i udbrud i forplejningszonen, og man stikker ikke af, hvis en rytter har signaleret, at han træder af på naturen vegne. Til gengæld, hvis en rytter sidder med i et udbrud uden at ville tage føringer, så bliver vedkommende i tydelige vendinger gjort opmærksom på, at de andre finder det uacceptabelt. Man skal have et alibi for ikke at tage sin del af slæbet ellers stigmatiseres man som unfair baghjulsslikker. ${ }^{6}$

Når sportsånden hyldes af velmenende folk, der står uden for selve sportskonkur- 
rencen, er det som antydet udtryk for en særlig ideologi, som mobiliserer en vilje til formynderi. Man vil noget med sporten. Man ønsker sporten, men netop i et højere formåls tjeneste. Sporten $i$ og for sig selv anses for meningsløs. Dens væsen måske ligefrem farlig. Den forsøges derfor tøjlet og tæmmet.

Men sporten er i sin stræben utæmmelig, og den dyrkes med selvfølgelighed som sådan af udøverne. På samme måde som professionalismen er en konsekvens af sportens fascinerende søgen mod stadige præstationsforbedringer, således er brugen af stimulanser og præstationsfremmende medikamenter det også. Når idrættens interessenter antager en uforsonlig holdning heroverfor, er det ikke mindst, fordi doping generelt fordømmes, dels af de politikere der direkte og bredt investerer midler i idrætten, og dels af dem der konsumerer idrætsunderholdningen, og dermed indirekte muliggør kommerciel idræt.

\section{Snyd og unfair vilkår}

Det mest indlysende argument mod brug af doping er, at det er snyd og skaber ulige vilkår. Holder vi os til cykelsporten som privilegeret eksempel, er dette argument imidlertid behæftet med den svaghed, at hovedparten af de konkurrerende cykelryttere ikke opfatter doping som utilbørlig snyd. Gjorde de det, ville de antageligt nægte at stille op i løb med dopingdømte ryttere, fremfor at strejke over forhør og undersøgelse af mistænke rytterkolleger, som tilfældet var i det famøse Tour de France 1998. At Festina-ryttere, der havde været hovedpersoner i dopingskandalen, umiddelbart efter Tour'en kunne køre løb i den schweiziske by Lausanne, uden at hverken deltagende eller ikke-deltagende ryttere protesterede, taler for sig selv.
Oveni kommer, at cykelentusiaster heller ikke synes, at dopingbrug er unfair. Derom vidner de mange opmuntringer til Festina, som var påmalet ruten, efter holdet var blevet ekskluderet. Det samme gjorde den støtte og opmuntring fra tilskuernes side, som på strejkedagen mødte de trillende ryttere. Og den ultimative understregning blev givet med det store fremmøde til løbet i Lausanne, hvor 'dopingsynderne' blev tiljublet som sande helte.

Hvis ikke konkurrenterne (og ej heller de passionerede tilskuere) opfatter doping som snyd, hvordan kan udenforstående da med vægt gøre gældende, at der er tale om snyd? Rytternes åbenbare holdning fremprovokerer helt anderledes overvejelser omkring snyd og ulige vilkår, som næppe gavner renhedsideologernes sag.

\section{Uinteressant ulighed}

Synspunktet, at doping gør sport uinteressant at overvære, fordi den sætter en ulighed mellem konkurrenterne, kan heller ikke fremføres med emfase, og da slet ikke hvis man i øvrigt ynder professionel idræt. Forskellen i sponsorstøtte etc. har forlængst gjort vilkårene aldeles ulige, kvaliteten af træning, faciliteter, muligheder, rådgivning, men også materiel og holdets styrke (hvad enten det beror på hjælperyttere eller som i fodbold medspillere) afhænger i høj grad af de økonomiske vilkår. Man må altså i det mindste tænke på tiden før moderne professionalisme, hvis man vil tænke lighed i konkurrence, og da er tanken endda illusorisk i betragtning af fysiologiens viden om, at mennesker af naturen er udstyret med betydelige forskelle. Doping kan måske ligefrem ses som en måde at kompensere for den uretfærdighed, at visse mennesker er udstyret med en større 'motor' end andre. 
Lægen og fysiologen Ludwig Prokop, der som idrætsmand har en fortid som østrigsk mester i svømning, fægtning og moderne femkamp, er ikke fremmed for en sådan betragtningsmåde. Skønt han er notorisk dopingmodstander og i øvrigt repræsentant for WHO, er han overraskende forstående overfor dopingbrugerne, hvilket kommer til udtryk i følgende formulering af miseren:

"Durch das extreme Leistungsprinzip im modernen Sport kommt dem Problem der Leistungssteigerung eine zentrale Bedeutung zu. Konsequente Konditionsarbeit und hartes Training als physiologische Wege zur Höchstleistung sind aber nicht immer vom erwünschten Erfolg begleitet, vor allem dann, wenn die genetischen Voraussetzungen nicht gegeben sind. Es ist daher verständlich, wenn Sportler versuchen, künstlich und wenn möglich mühelos, ihre Leistung $z u$ verbessern. Dagegen ist im Princip auch solange nichts einzuwenden, als die verwendeten Mittel und Methoden eine physiologische Unterstützung von Organfunktionen und des Stoffwechsels, z. B. im Sinne einer Substitution, darstellen. Die Vorstellung, da $\beta$ Pharmaka Leistungsmängel beheben oder eine verlorene Leistung zurückgeben können oder die Folgen eines unvernünftigen Lebens, einseitiger Überforderung, mangelnden Einsatzwillens oder des Nicht-Verzichtenwollens kompensieren können, beschränkt sich nicht allein auf den Sport. Sie spielt im Alltag und im Beruf, unterstützt durch unseriöse Werbeversprechungen, eine immer größere Rolle.?

Det, Prokop udtrykker forståelse for, er ærgerrigheden, som en indiskutabel drivkraft for sportsudøvelse på topplan. Uden den ville man ikke kunne give de nødvendige afkald og træne så determineret. Topsport er ikke kun sjov. Det er også ofre og surt slid.

\section{Sundhed og naturlighed}

Langt mindre forståelse udviser Prokop overfor mennesker, der bruger doping som erstatning for manglende vilje, en holdning han finder stadig mere fremherskende uden for sportens verden. Flere og flere do- per sig for at klare hverdagen. Med denne bemærkelsesværdige konstatering, baner han vej for den indsigt, at den udbredte fordømmelse af doping har rod i en opfattelse af sporten som en idealverden over for hverdagens anstrengende realverden. Fordømmelsen kan med andre ord ses i sammenhæng med sportens rolle som tilflugtsmulighed i det omfang, man nærer behov for at drømme sig bort fra hverdagens realiteter. Imidlertid er sportens verden en endog barsk realitet for dens fremmeste udøvere, hvorfor man umiddelbart kan undre sig over, at nogen med tilknytning til eliteidrætten kan give udtryk for undren og skuffelse, når sporten demaskeres og viser sig som ikke-ideal. Men dette tyder på, at for så vidt sporten fungerer som vor tids »opium for folket«, er det en funktion, der søges opretholdt af sportens 'kleresi': dens professionelle ledere og formidlere, og dermed kan dopingfordømmelsen paradoksalt nok ses som en konsekvens af folkets almindelige hang til 'dope'.

Når Prokop trods sin forståelse for dopingbrugen blandt eliten tager afstand herfra, er det primært på grund af sundhedsrisikoen.

Doping ist, medizinisch gesehen, ein unnatürlicher und unter Umständen ein lebensgefährlicher Weg zum Erfolg, mit dem letzten Endes nur Pyrrhus-Siege errungen werden können. Trotzdem rangieren die medizinischen Aspekte des Dopings für sehr viele Substanzen weit hinter den ethischen Aspekten der sportlichen Fairne $\beta$, denn Doping muß nicht immer gesundheitsschädlich sein. Es ist aber in allen Fällen unfair und verstößt gegen die sportliche Moral, denn die primitivste Voraussetzungen für jeden Wettkampf ist, Daß alle unter leichbaren Bedingungen antreten können. ${ }^{8}$

Det interessante ved denne argumentationsgang er, at den indeholder typiske elementer, men at de fremføres i atypisk ræk- 
kefølge, hvorved fordømmelsens problematiske grund træder desto tydeligere frem. At sundheden ligger ham særligt på sinde er forståeligt $\mathrm{i}$ betragtning af hans profession. Men samtidig sidder han som læge også inde med en nuanceret medicinsk og fysiologisk viden, der forhindrer ham i blankt at undsige enhver form for doping med hensyn til sundhedsfaren. Det er naturligvis mindre forpligtende at fremdrage dens unaturlighed, der, skønt dette ofte fremføres, ikke udgør nogen substantiel indvending, al den stund det at cykle og i det hele taget det at drive sport er unaturligt. Man kan naturligvis insistere på unaturlighedsargumentet og fremføre, at kroppen fungerer og tilpasser sig naturligt, hvad enten den løber, eller træder et kulturprodukt. Hermed har man privilegeret kroppens naturlighed, hvorefter man kan mene, at kulturen i hvert fald ikke hører hjemme i kroppens indre miljø.

Men det gør ikke sagen mere solid, for der er nærmest ingen grænser for, hvad vi indtager af kulturprodukter, som forrykker kroppens naturlige balance. Rygning og kaffedrikning kunne prompte forbydes, nødvendige undtagelser måtte indrømmes astmapatienter og naturligvis også mange andre med alvorligere sygdomme. Men man ville næppe kunne undslå sig for at sætte hårdt ind mod lagengymnaster, der med øget risiko for blodpropper (tilsvarende EPO) doper sig med p-piller (eller det højpotente middel Viagra) for at opnå visse fordele. Ligeledes ville det, som nu foregår til den store guldmedalje, være helt udelukket: at foretage kunstig befrugtning af kvinder, der ikke er i stand til på naturlig måde at opfylde deres hedeste ambition. Dette turde vise, at vi meget langt har lagt naturen bag os, og næppe kan bruge naturlighed som målestok for ret og rimelighed.

Prokop er tydeligvis klar over, at sund- hedsargumentet bestemt ikke er mindre problematisk. Derfor tyr han til moralen som afvisningsgrund, og kalder brugen unfair og uetisk. Men hvis det moralske skal tjene som argument, forudsætter det, at doping bestemmes som snyd, og vi har allerede set, at det næppe i alle tilfælde kan gøres meningsfuldt. Hertil kommer, at fairnessbegrebet under ingen omstændigheder kan bruges til en generel afvisning. F.eks. er det uanvendeligt til afvisning af synspunktet, at doping bør gives fri. Tværtimod kan det inddrages til støtte herfor.

Heroverfor er det sædvanligvis, at unaturligheden og sundhedsfaren bringes på banen. Men som vi just har set, har naturlighedsargumentet ikke rigtig noget for sig, og når sundhedsargumentet ikke er stort bedre, skyldes det, som Prokop eksplicit gør os bekendt med, at ikke alle dopingmidler med rimelighed kan siges at være helbredstruende. Hertil kommer en række andre forhold. En aldeles basal indvending er, at der ikke er noget sundhedsimperativ knyttet til sporten. ${ }^{9}$ Fremføres det alligevel, at sport $b \phi r$ være sundt, er et andet helt fundamentalt problem at bestemme, hvad der menes med sundhed..$^{10}$ Problemets omfang kan antydes med følgende udtalelse fra Festinas holdlæge, Daniel Blanc, der forsvarer brugen af doping på denne vis:

Hvis man vil have show, må man beskytte sportsfolkene, og den bedste beskyttelse er sommetider en smule $E P O$, der holder hamoglobintallet stabilt, så de ikke bliver tratte og ramt af hyppige infektioner. Det er bedre end at sende dem ubeskyttet ud i kraftprastationer.

Heldigvis for sportsfolkene er ikke alle lager hyklere. Nogle forebygger katastrofer på en ufarlig og ordentlig måde. ${ }^{11}$

Helt ubesværet stiller Blanc sagen på hovedet og promoverer det synspunkt, at dopingbrug givet under lægefaglig supervisi- 
on må forstås som en profylaktisk foranstaltning. Som ansvarlig læge føler han sig kaldet til at dope sine klienter af sundhedshensyn. I udgangspunktet sætter han fingeren på det ømme punkt, at dopingfordømmelsen ofte går hånd $\mathrm{i}$ hånd med ønsket om at se det højdramatiske og umenneskeligt strabadserende show, som cykelsportens store etapeløb er. Hvis en forudsætning for, at sport kan accepteres, er, at den ikke truer helbredet, har cykelsporten og en række andre yndede eliteidrætsgrene under alle omstændigheder et problem. Miseren er, at man ikke kommer uden om, at sportsudøvelse indebærer risici. Med den unge italiener Fabio Cassartellis dødsulykke i Tour de France 1995 in mente kunne man under henvisning til helbredsrisikoen derfor ligeså godt argumentere mod cykelsport i det hele taget og mod langt de fleste sportsgrene i øvrigt. Det gør dog kun de færreste, for de risikable shows er yndede.

Det er den realitet Blanc arbejder ud fra. På de givne præmisser forsøger han efter eget udsagn at minimere risikoen for showets professionelle aktører. Og at rytterne deler hans opfattelse, hører man i Bjarne Riis forsvar for professionel cykelsport, som han fremførte i TV 2 Sportens udsendelse »Piller og pedaler $«$, der fulgte op på den omstridte Tour. Efter at have karakteriseret strabadserne under et etapel $\varnothing \mathrm{b}$ som umenneskelige drager Riis en parallel til fodbold-VM, og påpeger forskellen i restitutionstid, som har betydning for præstationsevnen og sundhedstilstanden.

Vi skal op på cyklen naste dag igen og køre tohundrede kilometer, og der er måske to-tre bjerge. Der er vores problem bare, at vi har ikke seks dage. Vi er nodt til... Dermed siger jeg ikke vi er nodt til at tage doping. Vi er nфdt til at have, skal man sige, en sikkerhed. Derfor har vi lager med. Derfor har jeg f.eks. en akupunktør med. Derfor har jeg $i$ år haft en speciel mass $\phi r$ med. Derfor sørger vores lager for det første for, at vi får den rigtige kost, de rigtige vitaminer, mineraler, salte og sukker ekstra. Fordi jeg forbrander ca. 4 gange så mange kalorier som du gør. Du spiser en Multitabs hver dag. Jeg kan ikke ade sådan en håndfuld Multitabs hver dag. Det kan mine nyrer og min lever slet ikke arbejde med, så ville jeg stalde fuldstandig. Jeg er nodt til at have nogen hjoelpemidler, som kan gфre at jeg holder min standard, og at jeg stadigvak er sund og rask. Derfor har vi lagerne med til eventuelt at give os en... skal vi sige en bakster simpelt hen, som man måske ser syge mennesker få på hospitalet, hvor der er salte og mineraler i. [...]

Jeg er udmarket klar over, at for mange mennesker der er en sprøjte doping. Der kan man sige etik, og hvad ved jeg. Ja! Hvad er etik? At ryge 20 smoger om dagen eller at drikke ti $\phi$ l hver lordag-sфndag... Det er også sundt ik'?

Derfor har vi laegerne til at give os de ekstra ting som vi har brug for, for at holde helbredet sundt.

Selvfølgelig har vi nogen ting, vi skal have tacklet, det er vi alle enige om. Men vi skal ikke glemme, at det, der også er vigtigt, er, at vi skal komme sunde og raske til Paris. ${ }^{12}$

Dette forklaringsforsøg åbner svimlende perspektiver. Den direkte kobling, der etableres, mellem det etiske og det sunde er - skønt ikke uomtvistelig - interessant i lyset af, at det i den generelle fordømmelse sideordnet har været fremført, at doping er uetisk og usundt. Koblingen rammer måske hovedet på sømmet ved at demonstrere, at den fejlslutning ligger snublende nær: at doping er uetisk, fordi det er usundt. Følgelig er det bemærkelsesværdigt, at Riis, idet han erkender, at der er nogen ting cykelsporten skal have tacklet, udtrykker frygt for, at en indgriben over for cykelsporten kan få negativ indflydelse på rytternes sundhedstilstand. Han annoncerer med andre ord, at insisterer man på forbindelsen mellem det sunde og det etiske, kan det meget vel være uetisk at fare for hårdt frem imod gældende praksis i cykelsporten.

Fra udøverside betyder doping tilsyneladende gavnlig medicin, det er forbudt at ta- 
ge (og i lyset af hæmatokritværdigrænsen på halvtreds procent i UCI-regi måske endda med tilføjelsen: som opdages). Holdlægernes opgave består fremdeles i at hjælpe rytterne til - med alle lovlige midler og medikamenter - at klare sig bedst muligt i løbet, og at de kan gennemføre sunde og raske. Når Riis taler for brugen af ikke bare massage og akupunktur, men også for intravenøst føde i bemeldte bakster, anlægger han ligeledes et sundhedsmæssigt synspunkt. Det bruges profylaktisk. Det, der eventuelt kan anføres imod denne forståelseshorisont, er, at selve det at køre cykelløb, er at påtage sig en unødig sundhedsrisiko. Denne indvending kommer imidlertid til kort over for den almindelige borgers lemfældige omgang med sit eget helbred, som Riis henviser til. En henvisning der givetvis vinder gehør, idet det er en udbredt holdning i befolkningen, at det er udmærket, at der informeres om risici, men når det er sagt, priser man sig samtidig lykkelig for, at det endnu er den enkeltes ret at tage vare på sit eget liv og helbred, så vi stadig efter lyst og behov kan dope os gennem dagligdagen med kaffe, sprut og smøger.

\section{Sportens ligegyldiggфrelse}

Så langt har vi kunnet konstatere, at man ikke med de klassiske argumenter er i stand til at afvise enhver form for dopingbrug. Men nogle nye(re) argumenter er dukket op i debatten. Dels er der dem, der trækker på klassiske forestillinger om sportens forbilledlighed og karakterdannende værdi, og dels er der nogle private $\mathrm{i}$ den forstand, at de ekstrapolerer udfra en personlig afsmag. Disse argumenter har med smagen som præmis - et endnu mere yderligt og beskuende forhold til sporten end de klassiske.
En udmærket illustration er følgende udtalelse af redaktør for DGIs blad Ungdom og Idrat, Jens Sejer Andersen. Han mener, at en legalisering af doping vil blive sportens død, og begrunder det således:

Sporten vil miste sin forbilledvardi. En del af magien og fascinationen ved sport er forestillingen om, at det kunne vare mig, at det er almindelige mennesker, der via hårdt arbejde når deres mål. Med dopingen åbner vi også for genmanipulation, og hvis højdespringere skal have halvtreds procent langere ben end os andre, så mister sporten sin fortryllelse og muligheden for identifikation. [...] Når vi stadig med nogenlunde god samvittighed er tilskuere til eliteidratten, er det fordi den reprasenterer 'det gode'. Men uden forbilledvardien vil den kun reprasentere 'det sande' og afspejle den hårdtpumpede kemiske virkelighed vi lever i [...]

Det er en avisudtalelse, og som sådan vil det selvfølgelig være urimeligt at lade Sejer Andersen hæfte for fremstillingen. Ingen kan vide, hvilke nuanceringer der er gået tabt i den journalistiske profilering af Sejer Andersens synspunkt. Men citatet er, sådan som det fremstår, i sig selv interessant. Dels som kondensering af en række almene opfattelser der i forbindelse med skandalen er blevet promeneret i medierne, dels specifikt ved sin spillen på forskellen mellem 'det gode' og 'det sande'.

Tager vi det almene først, er det tvivlsomt, om der overhovedet er tale om en almenhed, der rækker ud over de pædagogisk- og opdragelsesorienterede ungdomslederes kreds. Udviklingen i forbindelse med den tiltagende professionalisering taget $\mathrm{i}$ betragtning er der næppe nogen indlysende grund til at mene, at sporten skulle miste sin forbilledværdi på grund af dopingbrug. De svimlende summer, som eksempelvis professionelle fodboldspillere tjener, har på sin vis undermineret forestillingen om, at de er helt almindelige mennesker. Ikke desto mindre (eller måske netop derfor) bliver de opfattet som fodbold- 
guder. Deres fænomenale kunnen, men også de astronomiske beløb de tjener og handles for, forlener dem med en overmenneskelig aura, der gør dem til større idoler og forøger deres forbilledværdi. Derfor opfattes det også som et problem for sporten, når de ikke opfører sig forbilledligt. Det er ikke betydningsløst, hvordan idolerne agerer i rollen som sportsstjerner. Det er f.eks. et dårligt eksempel for fodboldmålmænd, at se Peter Schmeichel undlade at løbe retur efter at været gået med i angrebet, som det skete i VM-kvartfinalen mod Brasilien. Derimod er det helt ligegyldigt, hvordan han gebærder sig i kontraktforhandlinger, eller hvordan han ellers gebærder sig uden for sporten arena. ${ }^{13}$ Omvendt er det et godt eksempel, når Riis - uden chance for selv at vinde løbet, men endnu med gode muligheder for en placering blandt de ti første - ofrer sig og tager Ullrich på hjul for at minimere hans tidstab på etapen til Lesdeux-Alpes. Hvordan Riis har kørt sig (eller på anden vis er kommet) i form, så han kunne bringe dette forbilledlige offer, hører hjemme uden for scenen. Det reducerer kun forbilledværdien, i det omfang der gøres en skandale af de eksterne forhold, og det ville selvsagt blive vanskeligere, hvis dopingbrug legaliseredes. Forberedelserne ville herefter atter være uinteressante for en større offentlighed, og interessen ville igen rette sig mod selve sportskonkurrencen.

Dette leder frem til andet led: at man ikke vil kunne identificere sig med de monstermennesker, der muligvis vil komme ud af komplet ukontrollerede forberedelser. Her tales om en mulig fremtid. Som eksempel nævnes muligheden for, at genmanipulerede højdespringere med ekstremt lange ben en dag vil blive en realitet.

Når dette eksempel umiddelbart er uheldigt, er det fordi genmanipulation, der påvirker længdevæksten, også $\mathrm{i}$ et fremtidsscenario med fuldt udviklede teknikker må formodes at skulle iværksættes senest, inden vækstzonerne lukker. Dvs. der skal foretages tvangsindgreb eller i hvert fald indgreb med samtykke fra umyndige personer. Hermed er vi på vej ind i en diskussion med et fundamentalt andet etisk indhold, som falder uden for denne artikels interessefelt. For emnet her er ikke dopingtvang, men frivillig dopingbrug. Det er blevet kendt, at man i det tidligere DDR systematisk gav dopingpræparater til børn, uden at de eller deres forældre blev informeret om, hvad det var, og hvilke bivirkninger det kunne medføre, ${ }^{14}$ ligesom man i Sovjetunionen sågar eksperimenterede med fostre og nyfødte med henblik på at skabe supermænd og -kvinder. ${ }^{15}$ Men at lægge disse afsløringer til grund for en generel afvisning af dopingbrug svarer til, at ville forbyde seksuelle relationer af enhver art med henvisning til voldtægters grusomhed.

Forestiller vi os nu alligevel, at det kunne lade sig gøre at genmanipulere folk i voksenalder til forøget benlængde, er det immervæk ikke indlysende, at sporten, som følge af disse usædvanligt langbenede højdespringere, skulle miste sin fortryllelse og mulighed for identifikation. Allerede nu er verdens bedste højdespringere ret langbenede og har i øvrigt en ganske særegen statur. Selvom det er fra naturens side, at de er udrustet med usædvanligt lange lemmer, er gennemsnitsmennesket alligevel uden realistiske muligheder for nogensinde at nå i nærheden af disse idrætsfolks springhøjder. Hidtil har det imidlertid ikke gjort deres præstationer mindre fortryllende, tværtimod. Ej heller har det forhindret, at man kan identificere sig med dem og tage ved lære af deres teknik, når man på atletikstadion selv prøver at forbedre sit personlige bedste. På samme måde som musik- 
interesserede børn og unge udmærket kan identificere sig med rockmusikere, der doper sig med sprut, speed, hash, og det der er værre, inden de går på scenen og trykker den af til ekstatiske højder. (Fremragende kunstnere som Jimi Hendrix, Janis Joplin og Jim Morrison døde alle, inden de var fyldt tredive, som følge af misbrug. Ikke desto mindre danser mange stadig begejstret til deres musik. De forargede - dengang i de sene tressere - var dem, der i forvejen foragtede musikken og var uden forståelse for dens kvaliteter.)

Det er en udpræget tendens, at jo mere fremragende (idræts)præstationer er, desto flere $\varnothing$ nsker at overvære dem, og der er ingen grund til at tro, at det pludselig skulle forandre sig, fordi metoderne til at producere dem ændres.

Følgelig er det heller ikke indlysende, at sport skulle blive uinteressant og miste sin fascinationskraft på grund af dopingbrug. Bjarne Riis' målrettede indsats for at vinde Tour de France er et sublimt udtryk for sportens væsen. I 1993 nummer 5, i 1995 på podiet som nummer 3, og endelig i 1996 som vinder. Hvad enten disse fantastiske præstationer er hjulpet på vej af EPO eller alene er blevet til på baggrund af en ihærdig træningsindsats under kyndig vejledning af hans læge dr. Checcini og akupunktøren John Boel, så var de under alle omstændigheder fascinerende... ligesom Pantanis store togt dette år. Det kan hverken indignation eller fordømmelse ændre ved, for fascination kan ikke fortrydes.

\section{Det gode eller det skфnne}

Den specifikke del af Sejer Andersens synspunkt har rod i forestillingen om sporten som moralsk værdi. Det, der gør, at vi kan se sport med god samvittighed, dvs. det der legitimerer sporten, er, at det re- præsenterer det gode, hævdes det. Således fremstillet er der tale om en fordrejning. Sagen er nemlig, at sporten af forskellige pædagoger er fors $\emptyset \mathrm{gt}$ inddraget $\mathrm{i}$ det godes tjeneste. Men det er, fordi sporten af væsen stiller udfordringer, som befordrer udvikling af egenskaber, der af nogen pædagoger er blevet regnet som gode. Eksemplet par excellence er Pierre de Coubertin, der så sporten som kongevejen til dannelse af den rette karakter. Hans hilsen til gymnastikfædrene Jahn og Ling er imidlertid bemærkelsesværdig:

Jahn var udelukkende optaget af at skabe militor styrke med det formål at samle Tyskland, og Lings mål var at фge og udbrede sundheden via fysisk aktivitet baseret pà videnskabelige principper.

Det blev overladt den store englander Thomas Arnold at genoptage grakernes vark, hvor det var blevet afbrudt ved skabnens ugunst, og tilføre det en paedagogisk udformning der passede til moderne forhold. Verden havde glemt, hvordan organiseret sport kan skabe moralsk og social styrke, og hvordan dem derigennem kan spille en direkte rolle i en nations skabne. ${ }^{16}$

Selvom Coubertin i sin promovering af sporten er ude i et pædagogisk ærinde, ser han væsensforskellen til gymnastikken. Nok er gymnastikken brugbar, hvis målet er at skabe en våbenduelig eller en sund befolkning, men den adskiller sig fra sporten ved sit formynderi. Som aktivitet er den i udgangspunktet styret og kontrolleret. Gymnaster disciplineres, idet de lærer at lade sig styre og kontrollere. Sporten er også disciplinerende, men på anden vis. Den er ikke styret og kontrolleret. Faktisk behøver sporten ifølge Coubertin »friheden til overdrivelse. Det er dens essens, dens mål, og hemmeligheden ved dens moralske værdi. $\ll{ }^{17}$ Det er op til udøverne selv at styre og kontrollere. Sporten appellerer fremdeles til kritisk vurdering, selvkontrol, beslutsomhed og ansvarstagning. Heri lig- 
ger sportens karakterdannende element. Rigtignok er der undertiden, også i sporten, en rollefordeling. Kan være der er en anfører, men der er ingen delingsfører. Dvs. nok kan man i sporten komme ud for at skulle indordne sig, men man underkaster sig ikke. Der er altid rum til personlig udfoldelse.

Det, Coubertin med andre ord har øje for, er, at sporten ikke som gymnastikken reprasenterer det gode, men fremkalder det. Det bemærkelsesværdige, ved det Sejer Andersen citeres for, er, at det udtrykker et syn på sport, som var det gymnastik. Hvor forskellige gymnastiktraditioner er blevet til udfra ideer om, hvad der er (moralsk) godt og (ideologisk) formålstjenligt, der knytter sporten sig snarere til det æstetiske. ${ }^{18}$ Enten narrer man sig selv, eller også har man ikke forstået sportens væsen, hvis man ser sport med god samvittighed, fordi det repræsenterer det gode. Sporten repræsenterer tværtimod, det skфnne. Det forstod Coubertin, der berømmede dens markante træk: »vilje, udholdenhed, intensitet, stræben efter fortsat forbedring og endelig et risikoelement $\ll .{ }^{19}$ Han talte varmt for sportens excessive tendenser og $\emptyset$ nskede $»$ bevar os vel for et samfund, hvor der ikke er plads til excesser «. ${ }^{20}$ Endog gjorde han sit til, at den nære forbindelse mellem sporten og æstetikken blev tydeliggjort. Således tog han initiativ til, at musik, litteratur og andre kunstarter blev en del af De olympiske leges program.

Med dette turde det være godtgjort, at dersom sporten ikke altid har haft et problem, så mangler der belæg for at mene, at det skulle være tilfældet nu, hvor det (atter) er blevet synligt, at sporten ikke er skabt eller drevet af interessen for det gode, men derimod for det skønne.

Når det, som vist, ikke er ligetil at finde holdbare argumenter mod frivillig doping- brug, skyldes det, at sporten, skønt organiseret, er selvstændig af karakter. Selvom den kan inddrages i pædagogisk eller sundhedsmæssigt ærinde, er den ikke foranstaltet med opdragelse eller sundhed for øje. Den nærer sig ved lysten til at dyste og kappes og er altså grundlæggende konfrontativ. I al enkelthed drejer den sig om overvindelse af modstand(ere). Når eksempelvis boksere slår handskerne sammen, før de begynder at kæmpe, udtrykker de med denne hilsen respekt for hinanden i sportens ånd, men netop som modstandere. Derefter reduceres den anden i overensstemmelse med sportens væsen til det, der skal overvindes. Slagserier sendes af sted uden hensyn til modstanderens ve og vel. Og har man held til at slå den anden knock out, holdes jublen ikke tilbage, tværtimod. Den vindende bokser løber triumferende rundt i ringen, mens taberen raver rundt på gulvet og forsøger at stable sig på benene. Når kamplederen har bekendtgjort resultatet, forenes kombattanterne i en omfavnelse, hvormed de uden nag takker for kampen - en gestus, der kan forekomme komplet uforståelig for den, der ikke er bekendt med sportsånden. Typisk gælder, at jo hårdere dysten har været desto længere vil omfavnelsen vare, som om sympatien med modstanderen stiger i takt med den ydede modstands størrelse. Det synes nærmest naturstridigt. Men det peger på, at det ikke er kampen, men modstanden, der er den primære attraktion ved sport. Det er ikke ligegyldigt, hvem eller hvad man kæmper mod. Derimod er det ligegyldigt, hvordan modstanden overvindes.

\section{Doping i historisk lys}

Det står enhver frit for at vælge at konkurrere på lavt niveau, og at minimere risici. Men sporten har alle dage animeret udøve- 
re til at give sig i kast med de største styrkeprøver og til at se bort fra risikomomenter. Lige så længe har disse forsøgt at dygtiggøre sig og øge deres præstationsformåen ved træning såvel som ved indtagelse af præstationsfremmende midler.

De tidligste eksempler kendes fra antikken, hvor atleter $\mathrm{i}$ forbindelse med de olympiske lege, forsøgte at styrke sig ved at inddrikke forskellige blandinger indeholdende vin og spiritus og spise svampe og planter med euforiserende virkning. Endog alkaloider som stryknin brugte man allerede dengang.

I moderne tid har doping været brugt siden anden halvdel af det 19. århundrede. Lad os se bort fra de kyniske hunde- og hestekure, hvor forsvarsløse dyr blev forberedt til væddeløb, og koncentrere os om det humane.

En kemiker fra Korsika, Angelo Mariani, blev omkring 1850 kendt for at lancere en drik, der blandt andet bestod af udtræk fra cocablade blandet op i vin. Denne såkaldte »vin for atleter « blev brugt af især franske cykelryttere. ${ }^{21}$ Uden for cykelsporten findes efterretninger om, at kanalsvømmere har brugt koffein i forbindelse med konkurrencer i Amsterdam i 1865. Det var dog fremfor nogen cykelrytterne, der har været pionerer udi dopingbrug. De udmarvende seksdagesløb gjorde det oplagt at søge metoder til at forøge udholdenheden. I den forbindelse fandt man ud af, at den såkaldte 'speedball', en mikstur bestående af heroin og kokain, var effektiv. Andre ting blev imidlertid også brugt. Belgierne var kendt for at tage sukkerknalder dyppet i æter; franskmændene mentes at bruge koffeintabletter, og englænderne at inhalere ren ilt foruden at tage stryknin, heroin og kokain, som de skyllede ned med brandy. ${ }^{22}$ Hensigten var selvfølgelig - foruden overhovedet at blive i stand til at udholde strabadserne - ligesom med træning at tilvirke sig en konkurrencefordel. Erfaringer med effektive miksturer og medikamenter blev udbredt i takt med landevejscyklingens indtog. Klassikeren Paris-Roubaix krævede antageligvis landevejscyklingens første dopingoffer allerede i 1896, da det kørtes for første gang. I hvert fald døde englænderen Arthur Linton under mystiske omstændigheder, efter at han var kommet $i$ mål som nummer fire. $\mathrm{Og}$ senere forlød det, at hans træner, den berømte og berygtede 'Choppy' Warburton, havde givet ham en 'trylledrik', så han trods total udmattelse kunne gennemføre løbet. ${ }^{23}$ Siden har cykelsporten oplevet en stribe dopingrelaterede dødsfald. Allerede omkring 1970 vurderede præsidenten for sammenslutningen af franske sportslæger professor ChailleyBert, at hidtil var mere end hundrede cykelryttere kommet af dage som følge af doping. ${ }^{24}$ Og alene i 1987-88 døde atten hollandske og belgiske cykelryttere af ukendte årsager. Eftersom de tilsyneladende intet fejlede, bredte den antagelse sig, at disse dødsfald relaterede sig til overdosering af EPO. ${ }^{25}$

De præstationsfremmende stoffer har dog ikke været forbeholdt cykelryttere. Ret tidligt bredte brugen af stimulanser sig til den $\varnothing$ vrige sportsverden. Ikke mindst de moderne olympiske lege - tro mod deres antikke forbillede - animerede til dopingbrug. I Saint Louis 1904 blev dopingbrugen for første gang dramatisk nærværende i forbindelse med OL, da den amerikanske marathonløber Thomas Hicks måtte genoplives efter løbet. Han havde taget store doser stryknin rørt op med rå æggehvider undervejs. $^{26}$ Fire år senere, da løberne første gang skulle løbe den nu klassiske marathondistance på 42,195 kilometer, resulterede dopingbrugen måske for første gang i diskvalifikation. Doping var ganske 
vist ikke forbudt dengang, men det var forbudt at få hjælp. Ude på ruten havde Dorando Pietri længe løbet afventende efter den førende sydafrikaner Hefferon. På trods af varmen og den høje luftfugtighed satte han tempoet i vejret, overhalede Hefferon og holdt det høje tempo for at sætte ham af. Han havde imidlertid overvurderet sig selv. Da han ankom til stadion, var han så udmattet, at han havde besvær med at orientere sig. Først var han ved at løbe den forkerte vej rundt, men han blev vendt om af behjælpelige funktionærer og vaklede mod mål. Flere gange faldt han undervejs, og da det skete igen få meter før målstregen, blev han hjulpet det sidste stykke af den tilstedeværende læge og forfatter, Sir Arthur Conan Doyle, (ophavsmand til den opiumsrygende detektiv Sherlock Holmes). Det var denne hjælp, der opfattedes som unfair og førte til diskvalifikation. Pietri havde angiveligt indtaget stoffet stryknin, som griber ind i kroppens temperaturregulering, og det kan ikke udelukkes, at han havde taget en for stor dosis i forhold til varmen. Dopingen kan således have været en faktor i forbindelse med hans kollaps. Men det er lige så troligt, at det var hans forcering på de afsluttende kilometre, der havde udtømt hans sidste ressourcer. Mange husker sikkert, da den schweiziske løber Gabriela Anderson-Schiess entrede det olympiske stadion i Los Angeles i 1984 $i$ en lignende forfatning, hvilket ikke skyldtes doping, men dehydrering. Det siger derfor meget om fordommene overfor doping i vor tid, at Hans Peter Rolfsen i sin beskrivelse af Dorando Pietris dåd ikke tøver med at begrunde hans kollaps med strykninen. ${ }^{27}$

En sådan fordomsfuldhed gjorde sig ikke gældende på Pietris tid. Var det sket i dag, var han blevet hængt ud som svindler. $\mathrm{Nu}$ levede han imidlertid $\mathrm{i}$ en anden tid og vandt i stedet berømmelse og idolstatus på sin heltedåd. Efter løbet blev han i bevidstløs tilstand kørt på sygehus, men han kom sig hurtigt. Som anerkendelse for sin tapperhed fik han en guldpokal af dronning Alexandra. Siden blev han hentet til USA for at løbe en række professionelle løb, og han vandt her en revanchematch afholdt $\mathrm{i}$ Madison Square Garden over den olympiske mester amerikaner John Hayes, der i det dramatiske løb i London også havde passeret Hefferon på det sidste stykke.

For $\varnothing v$ rigt blev Hefferon, efter diskvalifikationen af Pietri, af sine ledere opfordret til at protestere mod Hayes, fordi også han - ude på ruten - havde fået ureglementeret hjælp. Sydafrikaneren afviste dog. Efter sigende med den sportsligt storsindede begrundelse: 'Et sådant $l \varnothing b$ vinder man ved at være først over målstregen. Anderledes vinder man det ikke. ${ }^{28}$

Den yderst forsonlige omgang med styrkende og præstationsfremmende midler gør sig gældende et stykke op i dette århundrede. Først i 1960 - samme år som den danske cykelrytter Knud Enemark Jensen omkom ved OL i Rom under hundrede kilometer for hold efter indtagelse af amfetamin - udsendte Europarådet en resolution mod doping. Og så sent som $\mathrm{i}$ 1967 - efter Tom Simpsons endeligt på Mont Ventoux under Tour de France - reagerede IOC ved at udsende en liste over forbudte stoffer, der dannede grundlag for indførelsen af de systematiske dopingtest, der fandt sted første gang ved OL i Mexico 1968.

\section{Rationelle sundhedshensyn}

Det store tobindsværk Idrcet. Vor Tids store Folkeopdrager (1943) kan spore os ind på en forklaring af det markante holdningsskift, der nu kommer til syne som en veri- 
tabel dopinghysteri. Heri har lægen Ove Bøje bidraget med en artikel om idrætshygiejne, hvori han vier et afsnit til dopingspørgsmålet. Hans overvejelser bærer præg af en tankevækkende realitetssans, der sætter den aktuelle hysteri i relief. Bøje tager først selve begrebet i øjesyn og indleder med at konstatere:

I vore Dages Haarde Idratskonkurrencer vil man ofte sфge paa enhver Maade at opnaa det storst mulige Resultat. Det er derfor ikke markeligt, at man har tonkt sig, at det maaske var muligt at for $\phi g e$ Idratsprostationen ved at indtage et eller andet Styrkemiddel. Dette at forøge Idratsprastationen ved at indtage et Medikament kort før eller under Konkurrencen kaldes Doping. Selv om man paa Forhaand kan sige, at det er en Selvfolge, at man ikke maa anvende noget Middel til at satte Rekorderne $i$ Vejret, som kan have en skadelig Indvirkning paa Organismen, og der heller ikke er noget der tyder paa, at danske Amat $\phi r$ idratsmand anvender saadanne Midler, er det dog et Problem, der beskaftiger Tankerne saa meget, at det maa omtales.

Medens man ved Ordet Doping oprindelig forstod Stimulering af Idratsfolk ved starkt virkende Medikamenter, bruger man nu ogsaa Ordet Doping om alle Midler, ogsaa ganske uskadelige, der anvendes under Traning eller Konkurrence til at satte Ydelsen $i$ Vejret. Derfor kan man ogsaa kalde Anvendelse af Sukker, Vitaminer, Lysbestraaling og Ilt for Doping, det er blot en Strid om Ord, om man vil tage disse Midler med $i$ denne Sammenhang. Sukker og Vitaminer er allerede omtalt, det er normale F $\phi$ debestanddele, som givet $i$ ren Form og paa rette Tid kan gavne Idratsprastationerne uden samtidig at skade Sundheden. (min fremhavelse). ${ }^{29}$

Allerede her kan vi konstatere en i forhold til nutidens standard ganske forsonlig holdning overfor brugen af styrkende midler. Selvfølgelig vil man i idrætskonkurrencer forsøge at optimere sin præstation. Det har Bøje som idrætslæge forståelse for. Blot bekymrer han sig om sundheden. Han erklærer sig kun imod doping, for så vidt den skader organismen. I det kursiverede udtrykker han samme holdning, som den Samaranch fremkaldte forargelse og pro- test med under Tour de France, da han foreslog at revidere IOCs dopingliste og tillade ikke-sundhedsskadelige stoffer. Bøje ville, tør vi dømme udfra ovenstående citat, næppe have meldt sig i koret. Han giver sågar i artiklen råd om dopingbrug. Når han er skeptisk overfor brugen af »Højfjeldssollamper« som dopingmiddel, er det ikke fordi det er kunstigt, men fordi $\gg$ man bør foretrække det rigtige Sollys, der er baade kraftigere og billigere«. Men ellers er hans råd, at hvad enten man bruger »Sollys eller kunstigt Lys skal man begynde gradvis for ikke at blive for udmattet eller ødelægge Huden. ${ }^{30}$ Og det er ikke kun brugen af (kunstigt) sollys han viser forståelse overfor. Ganske vist tager han afstand fra brugen af kokain, men det er også på baggrund af rationelle sundhedshensyn. Efter at have lovprist kokainets evne til at lamme træthedsfølelsen, gør han opmærksom på, at »det er et meget giftigt Stof. Ved indtagelse af en større Dosis kan Døden indtræde i Løbet af kort Tid«. Desuden er der fare forbundet med indtagelse af selv mindre doser, idet det kan forårsage »en kronisk Forgiftning med fuldstændig sjælelig og legemlig Ødelæggelse, et Forgiftningsbillede, der kun kendes alt for godt fra de store Byer, hvor kokainet finder Anvendelse som Beruselsesmiddel. $\ll^{31}$

Efter samme recept tager han afstand fra brugen af Benzedrin »ferietabletter «. Stoffet »bruges ofte af Folk, der skal udføre aandeligt Arbejde i en Tilstand af Træthed og Uoplagthed. Det er nemlig i stand til at fjerne Træthed og Søvnighed « og det finder han $\varnothing$ jensynligt udmærket. Men da ferietabletter har en række bivirkninger, og det derfor er »muligt, at de nedsætter Idrætsydelsen mere, end det forøger den«, og at de ydermere ved længerevarende brug kan »skade Sundheden« mener han, at det bør forbydes. Men hermed lader han 
underforstå, at hvis det ikke skabte afhængighed og skadede sundheden, så var der ingen grund til at forbyde det. I tråd hermed er han i nogen grad positiv overfor koffein. Det er godt nok et giftstof

men det er ikke sikkert, at det har nogen skadelig Virkning, naar det kun bruges i smaa Mangder. Der foreligger ikke noget sikkert om, at Folk, der drikker meget Kaffe hele Livet igennem, bliver mere syge eller dør tidligere end andre Mennesker. Alligevel er det ikke ufarligt at anvende et Stof, der som Koffein pisker Organismen op til forøget Arbejde udover den Granse, den normale Træthedsfolelse satter. Koffein bør derfor ikke i ren Tilstand, hvor man let kan komme til at give for meget, anvendes som Doping. Derfor skal man ikke af overdreven Nidkarhed nedlagge Totalforbud mod Kaffe, Te og Chokolade. ${ }^{32}$

Koffein er altså ifølge Bøje et acceptabelt dopingmiddel, hvor det er naturligt forekommende, men også - ligger der implicit - i blandinger, hvor man ikke risikerer at give for meget. Med sin besindige tale imod overdreven nidkærhed gør han opmærksom på dopingforbudets kulturbestemthed og egentlige arbitrære karakter. Tydeligvis forstår han, at der i en rationel kultur må gives rationelle begrundelser for et dopingforbud.

\section{Den hellige sundhed}

Den tillid, Bøje nærer til videnskaben, gør sig imidlertid ikke gældende på samme måde i dag. Videnskaben betragtes nu med større skepsis. Kun de færreste fæstner lid til, at dens fremskridt vil føre til en forbedret menneskelig trivsel og helbredstilstand. Sundhedsforestillingerne er derfor langt hen blevet løsrevet fra de traditionelle sundhedsagenters område i moderniteten: naturvidenskaben. Sundheden er blevet et fritsvævende metafysisk begreb. Den er så at sige, hvad moderne mennesker har at klamre sig til, og er således kommet til at spille en fundamental rolle, blevet en absolut værdi.

I tråd hermed kan man forstå nutidens dopinghysteri som rodfæstet i en helliggørelse af sundheden, som så småt begynder midt i dette århundrede, og som siden 1970'ernes begyndelse er blevet iøjnespringende. Hermed ikke sagt, at der ikke tidligere har været interesse for sundhedstilstanden. Men sundhedsdyrkelsen var tidligere funderet på 'den hellige' videnskab, hvad enten vi tænker på myndighedernes investeringer i befolkningsomsorgen, eller vi betragter et privat-ideologisk initiativ som Lings rationelle gymnastik. Det er med rødder i denne videnskab, at Bøje gør sine synspunkter gældende. Den samme for $\varnothing$ vrigt som endnu i begyndelsen af dette århundrede ikke havde moralske skrupler over at undersøge mulighederne for endsige ved at hjælpe til - ad 'kunstig' vej at $\emptyset \mathrm{ge}$ atleters præstationsevne. I anden halvdel af dette århundrede bliver sundheden ikke bare sit eget formål, men også sin egen grund, hvilket afstedkommer en undertiden irrationel dyrkelse heraf. ${ }^{33}$

I stedet for at ofre sig i kampe til ære for guderne, som var et grundlæggende motiv i forbindelse med de antikke olympiske lege, så skal idrætten nu om dage først og fremmest tjene den hellige sundhed. ${ }^{34}$ Som følge heraf anlægges der fra statslig-officiel side en påpasselighedsstrategi, og derfor omfattes sporten - som samfundet i øvrigt - af stadig flere restriktioner. Hvad der truer, krænker eller lader hånt om sundheden, har ikke længere nogen legitimitet. Det må eksorciseres som en Lucifer. Den fundamentale rolle sundheden er kommet til at spille, viser både Daniel Blanc og Bjarne Riis (intuitiv) forståelse for i deres ovenciterede partsindlæg. Sundheden er blevet vor tids moralske grund. På den baggrund forstår man, at der tales om et doping- 
spøgelse, og at brugen af doping konsekvent må omtales som misbrug.

Den aktuelle dopingdebat er udtryk for et spændingsfelt mellem to diametralt modsatte holdninger i vor tid. På den ene side er der den position, majoriteten indtager, hvor sundheden holdes hellig. Her argumenteres udfra en grundlæggende forestilling om sundhed som en værdi i sig selv, uanset det drejer sig om bekymringen for de unge (jvf. argumenterne om tab af forbilledværdi og identifikatoriske muligheder), hensynet til moralen (jvf. argumentet om snyd og manglende fairness) eller det eksplicit er frygten for helbredsrisici (jvf. argumenterne om robotisering, kunstighed og usundhed), der føres i marken. Idet denne position valoriserer et rent og langt liv, og derfor nødigt vil tillade risici og excesser, indeholder den et element af livsfornægtelse.

På den anden side står en minoritet, in casu dopingbrugerne, fortalerne for dopingens frigivelse, med samt det entusiastiske publikum, der værdsætter og finder mening i sportsverdenens heltemodige præstationer og derfor hylder udøverne, til trods for at deres metier indebærer en kompromittering af sundhedshensynet. De ser sundheden som en selvfølgelig baggrund for fremragende præstationer og et anderledes meningsfuldt liv. Det, at udøverne såvel umiddelbart som på sigt er villige til at ofre sig på sportens alter, er netop med til at give sporten sin fascinationskraft. Det er offervilligheden, der hæver sporten ud af trivialiteten. Hermed viser atleterne sporten som et eksistentielt anliggende for dem, på samme måde som kunsten er det for kunstneren. Og det er som sådan, sporten kan engagere og blive meningsfuld for et medlevende publikum. Det er denne karakter, der gør, at sport har betydning som mere end et $\varnothing j$ jeblikkeligt tidsfordriv. Uden ville sporten være værdiløs. Den ville ikke have nogen historie. Fortidens præstationer ville være glemt, og der ville ikke være referencer for nutidens.

\section{Afslutning}

Vi er nu fremme ved en mulig forklaring til afløsning for den undren, som artiklen her udsprang af: Hvorfor er det for mange i dag af åbenbar vigtighed at bevare illusionen om en ren dopingfri (cykel)sport: Hvorfor opfattes doping som et særligt problem. Det skyldes ikke, hvad man ellers umiddelbart fristes til at tro, at det betragtes som unfair snyd. Løsningen ville i så fald ligge lige for $i$ form af en frigivelse af doping, og det kan ifølge majoriteten overhovedet ikke komme på tale.

Miseren er derimod, at sundheden er blevet hellig i vor tid. Sundhedsdyrkelsen, som ret beset er gold, idet sundheden under alle omstændigheder er dømt til undergang, forekommer at være blevet erstatning for en solid tilværelsesgrund. Det anses derfor som kættersk at omgå den lemfældigt. Der ses med mistro på de vantro, som i tale eller handling demonstrerer, at vejen til en meningsfuld tilværelse passerer påpasselighedens grænse. Det anfægter majoritetens højeste gode og må derfor fornægtes. Villigheden til at ofre sig for at give sin tilværelse indhold og perspektiv hinsides trivialiteten er tilsyneladende blevet ufattelig i vor tid, skønt menneskehedens historie er spækket med eksempler på martyrier og anden meningsrelateret offervilje. Derfor anslår majoriteten en formynderisk tone: Dopingforbudet må opretholdes for at beskytte sportsfolkene. Mod hvem? Mod sig selv? Nej mod interesserne der står bag. Mod de kyniske ledere og sponsorer, der tvinger - eller i hvert fald presser - dem ud i uføret. Det interessante 
ved denne argumentationsfigur er, at sportsfolkene fremstilles som værende umyndige og svage karakterer, hvilket synes paradoksalt $\mathrm{i}$ forhold til den autoritet og karakterstyrke de store profiler udviser i sportens verden. Men det oplagte alternativ, at anse ambitionen som det reelle problem, er ikke fristende for den, der både ser sundheden i sig selv som højeste gode og ønsker sporten som identifikatorisk mulighed. For sporten nærer sig ved ambition, og ville være ligegyldig uden. Da samtidig mådeholden ambition er en contradictio in adjecto, er det åbenbart, at sporten ikke kan tilbyde sig som reel identifikationsmulighed for den påpasselige hvis ikke som kompensation for den livsfornægtelse og -angst, der tegner sig i sundhedsdyrkelsen. Den naive illusion om sportens renhed er fremdeles udtryk for en tankevækkende ambivalens. På den ene side er der en udpræget fascination af spændingen og dramatikken i sporten, på den anden side en lige så udpræget fornægtelse af omkostningerne der er forbundet hermed. Derfor slås blikket ned, samtidig med at der slås syv kors for brystet, i det øjeblik det bliver synligt, at sundheden sættes på spil; derfor stemples dopingbrug som umoralsk; og derfor vælder det frem med skræk- og dommedagsvisioner om sportens fremtid, når brugen dokumenteres.

Konflikten står mellem den gode sundhed og den skønne sport. Idet sundheden gøres primær, kan det skønne kun accepteres som poleret og pletfri pænhed. Sporten gouteres kun som triviel underholdning. Dvs. bevidstheden bortcensurerer det sublime som manifesterer sig i forfølgelsen af ambition, hvilket i realiteten er det, der genererer sportens fascinationskraft og underholdningsværdi. Dette har vi fundet udmøntet i det synspunkt, at (cykel)sporten med ét bliver uinteressant, når vi bliver gjort bevidst om, at dopingbrug findes her, skønt intet er forandret.

Der hersker næppe tvivl om, at sporten ikke lader sig kujonere af sundhedens helliggørelse. Det ville stride mod dens væsen. Tør man gøre sig tanker om sportens fremtid synes to muligheder at tegne sig.

Enten vil sporten vise sig i besiddelse af en egen besindelse. En besindelse altså i samklang med dens væsen. Da vil der fortsat stræbes efter de mest fremragende præstationer. Træningsomfanget vil (om muligt) $\varnothing$ ges, træningsmetoderne vil forbedres, og dopingmidler vil fortfarende finde anvendelse. Men det vil ske inden for genkendelighedens horisont. Udøvere vil der fortsat være mange af, og fascinationskraft og underholdningsværdi vil være intakt. Efterhånden vil offentligheden tabe interessen for dopingbrugen, på samme måde som den har vænnet sig til professionalismen.

Alternativt vil sporten vise sig grænseløs. I så fald vil den bevæge sig hinsides genkendeligheden i overensstemmelse med dommedagsprofeternes varsler og måske i sidste ende befolkes af groteske genmanipulerede kroppe, som f.eks. højdespringere med to meter lange ben, skrumpehoveder og en minimal brystkasse til iltforsyning. Skønt groteske kroppe altid har haft øjeblikkelig appel, har de været ude af stand til at holde interessen fangen over tid. Så alternativet er på sigt, hvad dopingkritikerne annoncerer, at sporten $\mathrm{d} \varnothing \mathrm{r}$. Sker det, kan vi imidlertid blot græde tørre tårer. For så er der tale om en logik. Så er sporten syg, og så må den dø, ligesom andre organismer der vokser uhæmmet.

Men da sporten er en verden for sig, hvor der som sagt hersker en anderledes orden og moral, er det slet ikke sikkert, at denne sommers Tour var en forsmag på sportens dødskamp. For de sundhedsfikse- 
rede kan sporten endda vise sig at være foruroligende livsduelig. Måske er den største trussel mod dens fremtid i virkelig- heden den almindelige verdens vilje til at gribe ind i en sportsverden, den vasentligt ikke forstår.

\section{Noter}

1. Sylvester Hvid: Cycle-Haandbog for dem, der kører paa Cycle, og dem der endnu ikke er begyndt Rhodos Forlag, Kbh. u.å. (opr. ca. 1911).

2. Jvf. Ove Korsgaard: Kampen om kroppen, Kbh. 1982 s. $139 \mathrm{ff}$.

3. Se Jan Ove Tangens disputats: Samfunnets idrett. En sosiologisk analyse av idrett som socialt system, dets evolusjon og funksjon fra arkaisk til moderne tid, Oslo 1997.

4. Henrik Bay \& Nina Kragh: »De falske guder « $P$ olitiken, søndag 2. august 1998, 4. sektion s. 2.

5. Sociologen Gerhard Treutlein giver en anderledes udlægning af sådanne indenidrætslige forhold. Han ser en forskydning i forholdet mellem sportens målrationalitet og værdiorientering i retning af førstnævnte foranlediget af dopingmuligheden. Han siger: »Doping ist eine Handlungsstrategie, die notwendigerweise in ein Dilemma hineinführt. Es ermöglicht eine Steigerung sportlicher Leistungsfähigkeit, verstößt aber gegen den akzeptierten Wertehaushalt des Sports. Die beteiligten Personen und Organisationen versuchen diese verzwickte Situation mit hilfe von Verschleierung und Aussitzen zu lösen.« (Gerhard Treutlein: »Zwischen Wertorientierung und Zweckrationalität: Handlungsdilemmata im Leistungssport « in Karl Heinz Bette red.: Doping im Leistungssport - socialwissenschaftlich beobachtet, Stuttgart 1994, s. 154.) Når der må tages forbehold overfor Treutleins umiddelbart plausible forklaring, er det fordi, den forudsatter, at det, der 'udensportsligt' opfattes som et problem, også gør det 'indensportsligt'. Treutlein overvejer end ikke muligheden af, at der kan være en verden til forskel i vurderingen af doping. Dermed gør han sig blind for den mulige pointe, at det 'indensportslige' værdisystem holdes intakt samtidig med, at der i forhold til omverdenen gør sig en strategisk omgang med denne virkeligheds værdiforestillinger gældende, som viser sig i form af f.eks. tilsløringer. Når f.eks. cykelryttere, der taler offentligt om dopingproblemer i cykelsporten, bliver forstødt herfra, sker det ikke nødvendigvis, fordi rytterne vil dække over, at sportsånden er blevet korrumperet. Det kunne lige så vel være en

konsekvens af, at de der står frem har forbrudt sig mod den.

6. Den særegne moral der hersker i cykelsporten, har Roland Barthes tidligt beskrevet i sit uforlignelige essay »Tour de France - Cykelløbet som epos« in Mytologier Kbh. 1969.

7. Ludwig Prokop: Sport-Mißbrauch und Chance, Berlin 1992, s. 143.

8. Ibid. s. 150.

9. Dette er problematiseret i Hans-Volkhart Ulmer: »Sport und Präventivmedizin. Mens sana in corpore sano? i Doris Küpper og Lutz Kottmann red.: Sport und Gesundheit, Schorndorf 1991. Ulmer gør opmærksom på, at det nok er en udbredt tendens at forbinde sport med sundhed, men samtidig at det er et idealiseret skønmaleri, uden hold i virkeligheden.

10. Den diskussion skal ikke føres her. For en nærmere analyse af sundhedsbegrebets problematik se Verner Møller: Sundhed og idrat. Kulturanalyser til indkredsning af sundhedsaspektet $i$ idratten, Odense 1998.

11. TV 2 Sporten: »Piller og pedaler« 4. august 1998. 12. ibid.

13. At forbilledværdien falder, på grund af pressens tiltagende interesse for sportsstjerner som privatpersoner, hvorfor det slås stort op, hvis en forlader konen, får en fartbøde eller ender i værtshusslagsmål, kan dårligt lægges sporten til last.

14. Jvf. Hans Peter Rolfsen: Dopingsporten på sprøjten, Kbh. 1991.

15. Jvf. John M. Hoberman: Mortal Engines: The Science of Performance and the Dehumanization of Sport, New York 1992.

16. Pierre de Coubertin: Den olympiske idé. Taler og artikler Kbh. 1996, s. 34.

17. Ibid. s. 12.

18. Ling-gymnasternes anklage mod den danske gymnastik for at fremavle akrobater er interessant i denne sammenhæng, fordi den vidner om de 'sande og gode' mænds frygt for det uregerlige. For en nærmere redegørelse se f.eks. Else Trangbæk: Mellem leg og disciplin, Åbybro 1987.

19. Coubertin op. cit. s. 35.

20. Ibid. s. 24. 
21. Jvf. f.eks. Richard H. Strauss \& Timothy J. Curry: »Magic, Science and Drugs i Richard H. Strauss ed.: Drugs \& Performance in Sports, Philadelphia 1987.

22. Jvf. Robert Voy: Drugs, Sports and Politics, Illinois 1991.

23. Se W. Gronen \& W. Lemke: Geschichte des RadSports des Fahrrades, Hausham 1987, s. 191.

24. Ibid.

25. Jvf. Hoberman op. cit.

26. Jvf. Voy op. cit.

27. Jvf. Rolfsen op. cit. s. $75 f$

28. Jvf. Pea Nilsson: Marathonboken, Stockholm 1982.

29. Ove Bøje: »Idrætshygiejne« i Kr. Krogshede red.: Idrat. Vor Tids store Folkeopdrager, Odense 1943, s. 49.
30. Ibid. s. 50 .

31. Ibid. s. 52 .

32. Ibid. s. 53 .

33. For en uddybning heraf se min $»$ Den (ir)rationelle virkelighed « in Tendens nr. 2 Kbh. 1995.

34. Hvordan sundheden gerne ofres eller sættes på spil i kulturer, hvor 'sport' dyrkes med en anden religiøs forankring, er de mexicanske Tahamaru indianere et træffende eksempel på. I forbindelse med et frugtbarhedsritual løber de i et tidsrum mellem 24 og 72 timer et sted mellem 240 og 560 kilometer. Til gengæld er der ingen grænser for, hvilke midler de må tage $\mathrm{i}$ anvendelse for at holde ud og forøge deres fysiske præstationsevne. Som traditionelle teknikker bruger de at piske sig frem med tornede grene, og indtage substanser med strykninlignende effekt. Jvf. Hoberman op. cit. 